\title{
Internet for Empowerment: Access and Usages by the Women in Nepal
}

\author{
Assoc. Prof. Dr. Pradip Parajuli \\ Patan Multiple Campus, Tribhuvan University, Nepal \\ Assoc. Prof. Dr. Ganga K.C.* \\ Patan Multiple Campus, Tribhuvan University, Nepal
}

\begin{abstract}
Effective communication has the prospective to enhance women's quality of life, protect them in the fragile environment and create a knowledge based society that is more responsive to change and development issues. It can lead to the empowerment of women, enabling them to take control of their lives and participate as equals with men in development activities. The internet has made access to information and communication quick and easy with information. From entertainment to banking to access to resources related to education and health available at their fingertips. Internet services have a potential agent in the empowerment of women. This study found that exposer to the internet can help in gaining knowledge and change attitudes, which indirectly helps women gain freedom on all fronts. However, internet services have a very limited penetration among women in Nepal thereby limiting its impact on women empowerment.
\end{abstract}

Keywords: Access and Information, Communication, Gender, Internet, Peak using time, Prime using hours.

DOI: $10.7176 /$ RHSS/11-2-01

Publication date: January $31^{\text {st }} 2021$

\section{Introduction}

Communication is characterized as the exchanging of information and messages, and communication is performed through the media. Mass media denotes a segment of the media explicitly designed for a large audience to interact. With the emergence of national radio networks, mass-circulation newspapers, and magazines, the word was coined in the 1920s (Briggs \& Burke, 2010 cited in Mathur, 2013, PP. 2-3). This applies collectively to all media technologies used for communication, including newspapers, radio, television, and the internet, and to the organizations regulating these technologies:

In the early 1990s, the Internet arrived in Nepal. In 1993, in collaboration between the Royal Nepal Academy of Science and Technology (RONAST) and a private firm, Mercantile Office Systems (MOS), the Internet was first introduced to Nepal (Layton, 2002).

However, the early internet connection was slow and expensive. Nepal now has good internet connectivity, except in very remote areas and areas without access to electricity. The Internet has grown multiple folds in recent years in Nepal - in terms of penetration, speed, and cost-effectiveness (Acharya, 2018).

According to the Nepal Telecommunication Authority, there are nearly 23 million users of internet services, including those accessing them on mobile phones (NTA, 2020). The government of Nepal owned Nepal Telecom and a large number of private companies providing internet services. GSM mobile technology theoretically covers the entire county (although there may be some pockets where coverage is disrupted by topography), and they provide internet connectivity on mobile phones. More than 56 percent of Nepal's internet users access the internet through their mobile phones (NTA, 2020). Nepal has a fiber-optic cable backbone connecting the plains, districts, and neighbouring India (UNESCO, 2014, P. 86).

The internet and e-mail services are inching their way for profounder perception of the urban centres of Nepal. However, it will take several decades, if not more, for them to reach most educational institutions, government offices, and private sector office for information, business, entertainment, or personal communication (Kharel, 2007, P. 64).

The internet is being seen as the 'magic bullet' a solution to all the problems of development activities and programme. Yet, the rapid increase in the use of the internet in developing countries like ours is largely an urban phenomenon (Richardson, 1999, P. 1). The internet has multi-fold usages as well as there are multi-fold issues with the internet:

In connectivity, the internet has brought fundamental changes. It offers an opportunity for people to easily become manufacturers, mediators, analysts, and distributors of messages and opinions of any sort without additional costs, provided that the user has access to the internet and use an appropriate computer. Three key issues have arisen alongside the growth of the internet: access to the internet and its infrastructure, access to devices that facilitate access to the internet, and content on the internet (Acharya, 2012).

Internet is thought to facilitate women's empowerment. In developing countries, women use the internet to counter 
the injustice and discrimination that pose threats to their advancement (Choudhury, 2009). Women's access to internet training not only provided them the ability to close the gender digital gap but also to enhance their role and presence in society (Shirazi, 2012).

Similarly, a study conducted in Iran presented that the internet 'provide the women with the tools to effectively and efficiently participate in the broader public discourses,' however, 'these tools and services are not available in rural and less developed regions preventing female populations of these areas to participate in that public discourse' (ibid, 2012).

A similar study in Bangladesh concluded that:

... it may not be wrong to state that the internet is slowly awakening their inner selves as well as motivating and showing them the path toward achieving some form of empowerment in their lives. I would like to be optimistic here and believe that the internet has the potential to show them ways to be empowered. But it will all depend on women themselves if they want to use the knowledge and techniques acquired through the use of the internet (Choudhury, 2009).

\section{Objectives of the Study}

The broad objective of the study is to investigate access to internet services for women and their use habits in Nepal. This study also aimed to identify women's access to internet services, to examine the causes of using internet services, to find out the frequency of women on internet services, and to explore women's peak using time and prime using hours of internet services.

\section{Methodology of the Study}

The study has adopted descriptive as well as the analytical research design. The study area was identified using the multistage sampling method and the purposive sampling technique was adopted for selecting the sample. The research included women of different ecological regions, different development regions, and on the basis of rural and urban residence of Nepal. The nature of the data is qualitative as well as quantitative and both primary and secondary sources were used for data collection. Schedule interviews, observation, key informant interviews, focus group discussions and case studies were used to collect primary data and information for this study.

\section{Access}

In order to analyze the habits of using the internet or access of the respondents were asked whether they are using the internet or not. Their responses are presented in the table given below.

Table 1: Distribution of the respondent by access of internet

\begin{tabular}{|c|c|c|c|c|c|c|c|c|c|c|c|c|}
\hline \multirow[b]{2}{*}{ Variable } & \multirow[b]{2}{*}{ Classification } & \multicolumn{2}{|c|}{ Rural/ Urban } & \multicolumn{3}{|c|}{ Ecological Zone } & \multicolumn{5}{|c|}{ Development Region } & \multirow[b]{2}{*}{$\begin{array}{c}\text { Total } \\
\mathrm{N}^{*}=200\end{array}$} \\
\hline & & $\begin{array}{c}\text { Rural } \\
* \mathrm{~N}=120\end{array}$ & $\begin{array}{c}\text { Urban } \\
* \mathrm{~N}=80\end{array}$ & $\begin{array}{c}\text { Mountain } \\
* \mathrm{~N}=40\end{array}$ & $\begin{array}{c}\text { Hill } \\
* \mathrm{~N}=80\end{array}$ & $\begin{array}{c}\text { Tarai } \\
* \mathrm{~N}=80\end{array}$ & $\begin{array}{l}\text { Eastern } \\
* \mathrm{~N}=40\end{array}$ & $\begin{array}{l}\text { Central } \\
* \mathrm{~N}=40\end{array}$ & $\begin{array}{l}\text { Western } \\
* \mathrm{~N}=40\end{array}$ & $\begin{array}{c}\text { Mid- } \\
\text { Western } \\
* \mathrm{~N}=40\end{array}$ & $\begin{array}{c}\text { Far- } \\
\text { Western } \\
* \mathrm{~N}=40\end{array}$ & \\
\hline \multirow{4}{*}{$\begin{array}{l}\text { Access } \\
\text { of } \\
\text { Internet }\end{array}$} & \multirow{2}{*}{ Using } & 20 & 17 & 6 & 5 & 26 & 13 & 1 & 4 & 6 & 13 & 37 \\
\hline & & $16.7 \%$ & $21.3 \%$ & $15.0 \%$ & $6.3 \%$ & $32.5 \%$ & $32.5 \%$ & $2.5 \%$ & $10.0 \%$ & $15.0 \%$ & $32.5 \%$ & $18.5 \%$ \\
\hline & \multirow{2}{*}{ Not-using } & 100 & 63 & 34 & 75 & 54 & 27 & 39 & 36 & 34 & 27 & 163 \\
\hline & & $83.3 \%$ & $78.8 \%$ & $85.0 \%$ & $93.8 \%$ & $67.5 \%$ & $67.5 \%$ & $97.5 \%$ & $90.0 \%$ & $85.0 \%$ & $67.5 \%$ & $81.5 \%$ \\
\hline
\end{tabular}

\section{Source- Field Survey 2019}

The above table shows that only $18.5 \%$ of the respondents are using the internet. The majority of the respondents of $81.5 \%$ are non-users of the internet.

Respondents who have access to the internet were asked about the technology used to the internet. Their responses were presented in the table below.

Table 2: Distribution of the respondents by the technology used to access the internet

\begin{tabular}{|l|l|c|c|}
\hline Variables & Classification & Frequency & Percentage \\
\hline \multirow{4}{*}{$\begin{array}{l}\text { Technology used to access the } \\
\text { internet }\end{array}$} & Wireless / Broadband / ADSL / Fibre Optics & 13 & 6.5 \\
\cline { 2 - 4 } & WiMAX & 1 & .5 \\
\cline { 2 - 4 } & Mobile (GPRS, EDGE, 3G) & 22 & 11.0 \\
\cline { 2 - 4 } & Other & 1 & .5 \\
\cline { 2 - 4 } & Non user & 200 & 81.5 \\
\cline { 2 - 4 } & Total & 200.0 \\
\hline
\end{tabular}

\section{Source- Field Survey 2019}

The above data reveals $11.0 \%$ of respondents reported mobile (GPRS, EDGE, 3G) technology using for access internet. Only a few respondents, $6.5 \%$ reported that they are using wireless/ broadband/ ADSL/fiber optics for access internet service, and only $0.5 \%$ of respondents reported WiMAX technology for access the internet service. 


\section{Habits of Using Internet Service}

To analysis, the women's media habit on using the internet regarding causes, frequency, pick listening time, and prime listening hours hereunder.

\section{Causes}

To examine the reasons for using internet service respondents, their answers are shown in the table below, why you are using internet services.

Table 3: Distribution of the respondents by causes of using internet

\begin{tabular}{|l|l|c|c|}
\hline Variables & Classification & Frequency & Percentage \\
\hline \multirow{4}{*}{$\begin{array}{l}\text { Causes } \\
\text { using } \\
\text { internet }\end{array}$} & To access information (news / knowledge) & 17 & 8.5 \\
\cline { 2 - 4 } & For entertainment (audio / video / games) & 4 & 2.0 \\
\cline { 2 - 4 } & For connection with family / friends (Facebook/Skype) & 8 & 4.0 \\
\cline { 2 - 4 } & All of above & 6 & 3.0 \\
\cline { 2 - 4 } & Other & 2 & 1.0 \\
\cline { 2 - 4 } & Non user & 200 & 100.0 \\
\cline { 2 - 4 } & Total & & \\
\hline
\end{tabular}

Source- Field Survey 2019

The above table shows that $8.5 \%$ of respondents using the internet to access information (news/ knowledge). $4.0 \%$ of respondents reported that they are using the internet for connection with family/ friends (Facebook/skype). Few $3.0 \%$ of respondents reported that for all of the above, and only $2.0 \%$ of respondents reported for entertainment (audio/video/games).

Respondents were further asked which site you often visit on the internet. Most of the respondents reported that they are using google and Facebook, and few respondents responses that they are using email and skype.

Frequency

It was asked how much you use internet service to evaluate the level of use of internet respondents. In the table below, their answers are shown.

Table 4: Distribution of the respondents by frequency of using internet

\begin{tabular}{|l|l|l|l|}
\hline Variables & Classification & Frequency & Percentage \\
\hline \multirow{4}{*}{ Frequency of using internet } & Regularly & 16 & 8.0 \\
\cline { 2 - 4 } & Frequently & 18 & 9.0 \\
\cline { 2 - 4 } & Rarely & 3 & 1.5 \\
\cline { 2 - 4 } & Non user & 163 & 81.5 \\
\cline { 2 - 4 } & Total & 200 & 100.0 \\
\hline
\end{tabular}

Source- Field Survey 2019

The above table gives the frequency of using internet services. The above table shows that $9.0 \%$ of respondents reported that they are using the internet frequently. $8.0 \%$ of respondents reported that they are using internet services regularly, and only $1.5 \%$ of respondents reported that they are using the internet rarely.

\section{Peak Using Time}

The respondents were asked to indicate what time of day are using the internet. Information solicited in this regard covers, the time when most respondents open the internet (peak using time). Respondent's responses are given below in the table.

Table 5: Distribution of the respondents by most using internet time

\begin{tabular}{|l|c|c|c|}
\hline Time & Often & Sometimes & Total \\
\hline \multirow{2}{*}{ Morning } & 6 & 7 & 13 \\
\cline { 2 - 4 } & $3.00 \%$ & $3.50 \%$ & $6.50 \%$ \\
\hline \multirow{2}{*}{ Afternoon } & 6 & 11 & 17 \\
\cline { 2 - 4 } & $3.00 \%$ & $5.50 \%$ & $8.50 \%$ \\
\hline \multirow{2}{*}{ Evening } & 5 & 3 & 8 \\
\cline { 2 - 4 } & $2.50 \%$ & $1.50 \%$ & $4.00 \%$ \\
\hline \multirow{2}{*}{ Night } & 4 & 2 & 6 \\
\cline { 2 - 4 } & $2.00 \%$ & $1.00 \%$ & $3.00 \%$ \\
\hline
\end{tabular}

Source- Field Survey 2019

The above table shows that $8.5 \%$ of respondents using the internet in the afternoon. $6.5 \%$ of respondents reported that they are using the internet in the morning. $4.0 \%$ of respondents reported that they are using the internet in the evening, and only $3.0 \%$ reported that they are using the internet at night.

Prime Using Hours

Respondents were asked, the time they prefer to use the internet (prime time). Detailed respondent's responses are shown in the following graph. 
Figure: Distribution of the respondents by prime using hours of internet.

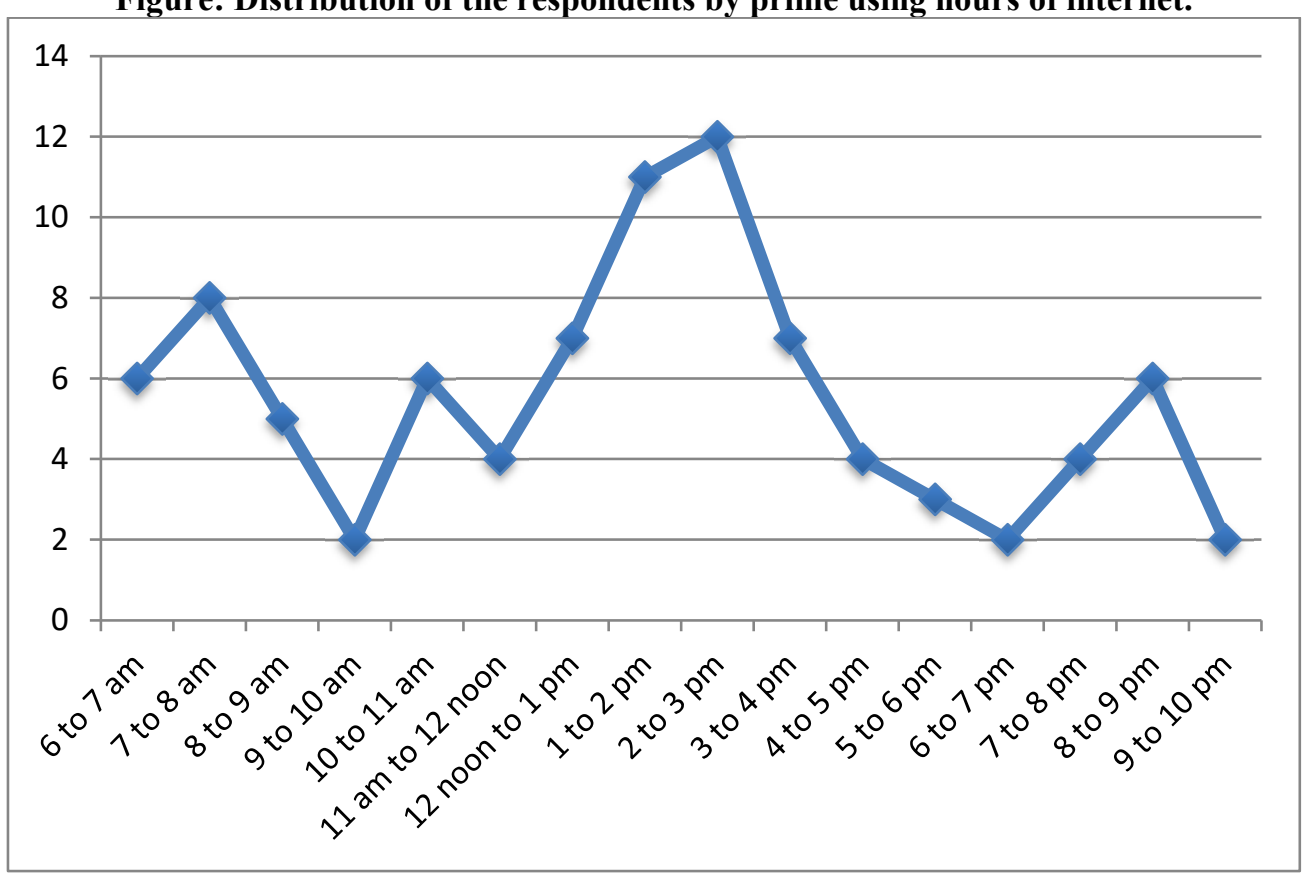

The above graph shows that the most preferred (prime using hours) time to use the internet was afternoon 23 PM. Only a few respondents are preferred using the internet during the morning and night.

\section{Findings of the Study}

- Only $18.5 \%$ of the respondents were using the internet. A large majority of the respondents $(81.5 \%)$ were non-users.

- $11 \%$ of respondents used mobile (GPRS, EDGE, 3G) technology for accessing the internet. A few respondents, $6.5 \%$, used wireless/ broadband/ ADSL/fiber optics for accessing the internet services, and only $0.5 \%$ of respondents accessed the internet using WiMAX technology.

- $\quad 8.5 \%$ of respondents used the internet to access information (news or knowledge), $4 \%$ of respondents accessed the internet for connecting with family/friends. A few, 3\% of respondents, used the internet for all types of activities, and $2 \%$ of respondents used it for entertainment (audio/video/games).

- $\quad 9 \%$ of respondents frequently used the internet. $8 \%$ of respondents used the internet services regularly, and $1.5 \%$ of respondents rarely used the internet.

- $8.5 \%$ of respondents used the internet in the afternoon, $6.5 \%$ of respondents used the Internet in the morning, $4 \%$ of respondents used the Internet in the evening and 3\% used the internet in the night.

- $\quad$ The most preferred time to use the internet was 2 to 3 PM.

\section{Conclusion}

Internet services have made access to any information and communication very fast and easy. Internet services have a potential agent in the empowerment of women. The expose to the internet can help in gaining knowledge and change attitudes which, indirectly helps women gain freedom at all fronts. It influences the social, political, and economic dimensions of women. Though, internet services have a very limited penetration among women in Nepal.

\section{References}

Acharya, U. (2012). Online Media in Nepal: A Need for Policy Intervention. Alliance for Social Dialogue: Kathmandu. Last accessed on October 1, 2020, at http://research.butmedia.org/wpcontent/uploads/2013/09/online_media_in_nepal_UjjwalAcharya.pdf

Acharya, U. (2018). Media Landscape: Nepal. European Journalism Centre. Last accessed on October 1, 2020, at https://medialandscapes.org/country/nepal/

Ayadi, A. B. (2001). Role of Mass Media on Nepal-India Relations: A Content Analysis of Selected Nepali and Indian Newspapers on the Trade Embargo (1989) and the Mahakali Treaty (1996). Unpublished Master's thesis. Tribhuvan University, Nepal.

Batliwala, S. (1993). Empowerment of Women in South Asia: Concepts and Practices. Asian-South Pacific Bureau of Adult Education: New Delhi. 
CBS (2012).Statistical Pocket Book of Nepal. Kathmandu: Central Bureau of Statistics.

Choudhury, N. (2009). The Question of Empowerment: Women's Perspective on Their Internet Use. Gender, Technology, and Development, 13(3), 341-363. https://doi.org/10.1177/097185241001300302

Kharel, P. (2007). Dimensions of Communication. Kathmandu: Nepal Association of Media Educators.

Layton M. (2002). NGOs and the Internet in Nepal, Journal of Computer-Mediated Communication, Volume 7, Issue 2, 1 January 2002, JCMC725, https://doi.org/10.1111/j.1083-6101.2002.tb00141.x

Mathur, C. K. (2013). Mass Media and Democracy in India: A Political Study of Their Relationship in PostEmergency Period. Unpublished doctoral thesis, University of Delhi, India.

NTA (2020). MIS Report, Year: XVII, Issue 141, Vol. 190. Last accessed on October 1, 2020, at https://nta.gov.np/wp-content/uploads/2020/11/2077-MIS-Bhadra.pdf

Richardson, D. (1999). The Internet and rural development. In Special: The first mile of connectivity. Retrieved May 7, 2014, from http://www.fao.org/docrep/x0295e/x0295e13.htm

Shirazi, F. (2012). Information and communication technology and women empowerment in Iran, Telematics and Informatics, Volume 29, Issue 1, Pages 45-55. https://doi.org/10.1016/j.tele.2011.02.001

UNESCO (2014).Assessment of Media Development in Nepal. Kathmandu: UNESCO. 